\title{
Prayer and meditation among Danish first time mothers-a questionnaire study
}

\author{
Christina Prinds ${ }^{1,2^{*}}$, Dorte Hvidtjørn ${ }^{1}$, Axel Skytthe ${ }^{3}$, Ole Mogensen ${ }^{4}$ and Niels Christian Hvidt ${ }^{3}$
}

\begin{abstract}
Background: Mothers' existential dimensions in the transition to motherhood have not been described thoroughly. They might experience disruption and new perspectives in existential ways and this may especially be the case in preterm birth. The aim of this study was twofold. First we investigated the existential dimension of motherhood transition in a secularized context, through practices of prayer and meditation. Second we described the relationship between time of birth (term/preterm) and the prayer/meditation practices of the mothers.

Methods: Data were gathered from a nationwide questionnaire survey among first time mothers conducted during the summer 2011. All Danish women who gave birth before the $32^{\text {nd }}$ pregnancy week $(n=255)$, and double the number of mothers who gave birth at full term $(n=658)$ in 2010 were included (total $n=913)$. The questionnaire consisted of 46 overall items categorized in seven sections, which independently cover important aspects of existential meaning-making related to becoming a mother. The respondent rate was $57 \%(n=517)$.

Results: Moments of praying or meditation 6-18 months post partum were reported by $65 \%$, and mothers who responded affirmatively, practiced prayer $(n=286)$ more than meditation $(n=89), p<0,001$. We did not observe differences in affirmative responses to prayer or meditation between mothers of full term or preterm born children, not even after controlling for perinatal or post partum loss, mode of birth, age, status of cohabiting or education.

Conclusions: In this explorative study we found specific practices of existential meaning-making through prayer and/or meditation among first time mothers, living in a very secularized context. Yet we know only little about character or importance of these practices among mothers, and hardly anything about existential meaning-making among new fathers. Hence the implications of meaning-making practices related to other dimensions of health are difficult to address in a qualified way in care for new mothers and families.
\end{abstract}

Keywords: Motherhood, Prayer, Meditation, Meaning-making, Childbirth, Preterm birth, Existential, Religion, Spirituality

\section{Background}

\section{Beginning of life and end of life}

In recent decades there has been an increasing amount of research on the manifold forms of making meaning at the end of life among patients and relatives. Some of this research addresses existential, spiritual or religious considerations and needs, and suggests that they intensify when facing the end of life $[1,2]$. In spite of this, research suggests that such considerations are not met adequately in the health care system $[3,4]$.

\footnotetext{
* Correspondence: cprinds@health.sdu.dk

'Department of Clinical Institute, University of Southern Denmark, J.B. Winsløws Vej 19, DK-5000 Odense, C, Denmark

University College South Denmark, Degnevej 16, 6705 Esbjerg $\varnothing$, Denmark

Full list of author information is available at the end of the article
}

Spiritual ways of making meaning is a focus in the field of palliative care related to the end of life, but it is not addressed at all in maternity services in Denmark $[5,6]$. In relation to the beginning of life, health care research related to existential meaning-making remains limited, even in the paradoxical situations where the beginning and end of life sometimes coincide, for example in some cases when giving birth preterm. Previous research suggests that the impact of considerations related to the beginning of life may be similar to those at the end of life. These events are gateways that encircle life, and both of them may facilitate considerations related to existential meaning making $[7,8]$. This study concentrated on a specific practice of existential 
meaning-making, namely prayer and/or meditation when becoming a mother for the first time in a secular context.

\section{First time motherhood at term or preterm}

Motherhood as an existentially transformative process has been explored in psychological and anthropological research [9-11]. A recent literature review argues that the joy of birth has been neglected in literature, thus leaving out any spiritual or sacred meaning [12]. Childbirth has been understood as a journey into "...motherland" [13] "... a miracle" [14] "... a religious act" [15] and even as "...a sacrament" [16]. In a society known to be the most secular in the world [17], it may seem provocative to study first time motherhood in such terms. Recent Danish research among other groups of patients, though, has found reflections related to existential meaning-making to be intensified during illness. In relation to cancer, a recent survey among patients with severe lung cancer showed that $64 \%$ had some belief in God and/or a spiritual power [18]. An interview study among young leukemia patients found that existing beliefs related to meaning-making (both religious and non-religious) prior to cancer were strengthened during illness [19]. Ausker described one of her informants having experienced becoming a mother as a life threshold similar to her experience of leukemia [19, p. 132]. On the basis of the latest European Value Survey (EVS) among 1507 Danes in 2008, Andersen et al. analyzed the religiosity of Danes in a lifetime perspective. They found beliefs to be quite stable, independent of age, but sensitive to intense life events, as for example childbirth or serious illness [20].

Giving birth preterm may be even more existentially transformative since the period of the beginning of life is potentially confronted with the end of life. Mothers of preterm born children may suffer from post-traumatic stress and anxiety [21], and some are found to develop potentially problematic attachment styles in the mother-child relation [22]. Preterm birth is the leading cause of perinatal mortality and morbidity globally [23], which, in many countries ensures special care of parents in maternity services. This is also the case in Denmark [6]. The impact of preterm childbirth on motherhood was studied in Denmark among parents of 66 neonates in 2008. Among the mothers, $30 \%$ met the criteria for Post Traumatic Stress Disorder (PTSD) either clinically or sub-clinically [24]. In relation to motherhood of preterm born children in general, practices of existential meaning-making have not previously been studied in Danish health care research. Other aspects of preterm childbirth in Denmark have been studied recently, for example the challenge concerning the construction of motherhood related to a moderate preterm child [25]. Also the phenomenon of christening of newborns in acute situations at the hospital, has been explored and found to be potential significant to parents [26].

\section{Prayer and meditation practice}

Existential meaning is a multidimensional construct explored in different ways. Whereas religion in an earlier European context was an obvious and normal sociocultural source of meaning during illness, it seems to have lost its importance in western medicine today [27]. The increased focus on science-based and evidence-based medicine might also induce a more private process of making meaning, since issues of an existential character are not obviously important in medical research $[28,29]$. To study existential meaning-making, Danish researchers, on the basis of a literature review, have proposed a new conceptual framework for existential meaning-making, consisting of three dimensions: cognition, practice and importance [30]. In this study we focus on the practice dimension of existential meaning making, especially religious or spiritual practices, namely prayer and meditation.

Meditation practices have been studied in a randomized controlled trial among nulliparous women in Denmark, focusing on the effect of the practice of hypnosis during birth in relation to pain and the experience of childbirth. The study showed that overall, women randomized to hypnosis had a better childbirth experience than the two control groups [31]. In antenatal education classes in Denmark, there has been a tradition of spiritually oriented practices like visualization and mindfulness and yoga [32,33].

Prayer and/or meditation practices have been studied among other groups in Denmark. 480 hospitalized people and their relatives at Copenhagen University Hospital (Rigshospitalet) participated in a questionnaire survey about faith in 2006. Sixty-two percent replied affirmatively to the question: "Do you take some moments of prayer, meditation or contemplation or something like that?" [34] When asked in population based values surveys, Danes do not pray much. According to the EVS in 2008, $50 \%$ percent responded to the statement "How often do you pray to God outside of religious services?" with 9 options ranking from Every day to Never, the choices being dichotomized between Less often and Never. Of these answers, $55 \%$ were in the "A few times a year" or "Less often than a few times a year" options. $48 \%$ reported that they never prayed [35]. ${ }^{1}$ When asked "Do you take some moments of prayer or meditation or something like that?" $48 \%$ replied affirmatively and $51 \%$ replied negatively [35]. In a Danish questionnaire survey exploring familial resemblance in religiosity among 6707 participants of comparable age from 2009, 48 \% gave a positive answer to the statement "How often do you pray to God outside of religious services?" $51 \%$ reported that they never prayed. The mean age in the study was 29 years, $60 \%$ of the respondents being women [36]. There seems to be a difference between responses from hospitalized patients and relatives and the more population-based surveys on prayer, indicating that a 
practice such as prayer or meditation increases when being hospitalized.

Mothers in other studies, based on data from primarily Western countries, giving birth is highlighted as something holy, a spiritual experience or blessed event [15, 16, 37]. We have no knowledge as to whether Danish mothers turn to religious or spiritual dimensions of making meaning of life, including practices of prayer and meditation, or whether there are different practices between mothers giving birth at term or preterm. Hence we do not know if or how to address this dimension of life and health in the maternity service, or whether we should differentiate between care for mothers of preterm born children or children born at term. The aim of this study was thus firstly to investigate practices of prayer and meditation among Danish first time mothers, and secondly to distinguish between mothers who gave birth at full term (FT) or preterm (PT) in terms of their respective prayer/meditation practices. On the basis of previous research related to preterm birth, we hypothesized mothers of preterm born children would practice prayer/meditation more than mothers of full term born children. On the basis on existing research related to prayer and meditation, we hypothesized that meditation practices would be more widespread than prayer among Danish first time mothers.

\section{Methods}

We used data from a cross sectional questionnaire survey among Danish first time mothers who gave birth in 2010. We retrieved information from the Danish Medical Birth Register about all mothers who gave birth before the 32nd week of gestation in Denmark and twice that number of women who gave birth at full term, randomly sampled. Mothers experiencing perinatal or post partum loss (stillbirth after the $22^{\text {nd }}$ pregnancy week or death post partum, covering up till 100 days post partum) were also included. Mothers of twins, who lost one of them, were categorized as mothers of a living child. In the present paper, mothers who gave birth at full term will be called full term (FT) mothers), whereas mothers who gave birth before the $32^{\text {nd }}$ pregnancy week go as preterm (PT) mothers. We included only first time mothers who had given birth in 2010, in order to reduce the risk of recall bias if the experience of becoming a mother was older than 18 months. The free of charge antenatal care in Denmark encompasses almost all pregnant women (99 \%) [38], which makes the national registration almost complete.

In July 2011, a postal questionnaire about existential meaning making in motherhood was sent to all participants along with a covering letter. Reminder letters were sent 10 weeks later [39]. No incentives were given. The Regional Research Ethics Committee of South Denmark approved the study, and the exact registration number from The
Danish Data Protection Agency was submitted in the covering letter, which also explained the voluntary nature of participation and the right to withdraw at any time [40]. In line with national regulations participation was obtainment of informed consent [41]. Responses were scanned by a consultancy company (UNI-C), and delivered to researchers in STATA-format and, for long accounts, in SPSS-format. We conducted random checks for consistency between scans and the original questionnaires. All questions from validated questionnaires are reported in an original translated version, and translation of the remaining questions into English were done firstly by the first author, and secondly by a professional translator (MC).

\section{Survey construction}

The questionnaire consisted of 46 general items categorized in seven sections, which independently cover the most important aspects of existential meaning-making related to becoming a mother and the pregnancy, birth and post partum periods respectively. The questionnaire was structured to differentiate between different forms of meaning-making. Existential meaning-making is an overall concept linked to both secular, religious and spiritual orientations. Especially in Northern Europe it is also derived from more secular viewpoints [30]. As explained in the introduction, in 2010 the Danish researchers, la Cour and Hvidt, proposed a conceptualization in which the existential is the broader concept, encompassing both existential philosophical values and ideas without any transcendent foundation (secular), as well as meaning orientations related to spiritual and/or religious notions [30]. They propose to apply the three domains: knowing, doing and being to the three dimensions of secular, spiritual and religious meaning-making within a "matrix", to explore consistency between the concepts of cognition, practice and importance. The three concepts of knowing (cognition), doing (practice) and being (importance) were introduced by the sociologist Fishman [42] and have been found to have good explanatory power in the analysis of the Danish items related to meaning-making in the European Values Study [43].

The structure of the questionnaire was based on this "matrix", as well as an underlying understanding of the pregnancy, birth and post partum periods as periods that may actualize existential reflections either partially or as a whole. In the interpretation of findings we also relied on this underlying understanding. As earlier mentioned, we focused in this particular study on those items in the questionnaire that concerned the practice dimension, in particular prayer and meditation.

The items in the questionnaire were developed on the basis of a pilot study, a qualitative interview study among Danish mothers of preterm born children in 2008 [44], as well as on the basis of various other surveys, for example 
items from the EVS (2008), the Views and Values Survey from the Danish Twin Registry (2009) and the third edition (2008) of the survey concerning religion from the International Social Survey Programme [45]. Items were identified also from an extensive literature review focusing on the existential dimensions of the transition to motherhood among new mothers in other Western oriented countries [46]. According to Nørregaard-Nielsen and Østergaard [47], draft questionnaires were tested among midwifery and public health researchers. On the basis of this process, the questionnaire was revised and then pilottested through face-validation with new mothers in one focus group interview and six individual interviews [40, 48].

\section{Core question}

In this paper we focus on and differentiate the item "Do you take some moments of prayer, meditation or contemplation or something like that?" (See item 28 below). This item was designed to provide knowledge about religious and spiritual practices among Danish mothers. It has been used in the EVS 2008 and in a survey among hospitalized patients and their relatives at the Danish Rigshospitalet [34]. In contrast to the previous use of the item, in this questionnaire the options for answering the question were specified, partly to distinguish between religious and spiritual practices and partly to explore how Danish mothers understand such practices. The respondents were allowed to select one or more of the different forms of praying or meditation. Furthermore, we looked into three supplemental items $(18,22 \& 25)$, which were used previously in the EVS or ISSP to search for internal consistency between the dimensions of knowing, doing, and being. Consistency between the dimensions is represented when for example respondents who accept prayer as a dialogue with God (item 28), are also admitting to some kind of belief in a God (item 25) (See Table 1).

\section{Statistics}

Data was analyzed using Stata version 13.0 [49]. Categorical data were analyzed using the chi-square test of independence and binomial regression was used to control for confounding for perinatal or post partum loss and mode of delivery. Difference in age was tested using a two-sample $t$-test. $P<0.05$ was considered statistically significant. Respondents answering, "don't know" were included in all analyses, whereas missing or faulty answers were omitted in analyses [50].

We reduced the item concerning prayer to God outside religious services (item 22) into four subgroups. Firstly, one group praying regularly, divided between " $a t$ least once a month" and "several times a year". Secondly, the biggest group of respondents, reporting prayer several times a year or less often than that, and thirdly, a
Table 1 Core question

\begin{tabular}{ll}
\hline Item & Question \\
\hline 28 & Do you take some moments of prayer, meditation or \\
contemplation or something like that? (no/yes) \\
If yes, please explain using the phrases below how \\
you understand prayer or meditation: \\
Prayer in church or at other religious gatherings \\
Prayer as an inner dialogue addressed to God \\
Prayer as an inner dialogue addressed to 'something \\
greater than myself' \\
Prayer as a physical act, e.g. kneeling, folding your \\
hands \\
Prayer as music, e.g. hymns, spirituals \\
Meditation as a physical activity \\
Meditation as a spiritual activity \\
Meditation as a means to maintaining or achieving \\
good mental health \\
Something else, please state what:
\end{tabular}

Three items concerning existential reflections in the knowing- and being dimensions:

18 (being) Independently of whether you go to church or not, would you say you are...

A religious person

A non-religious person

A convinced atheist

Don't know

22 (doing) How often do you pray to God outside of religious services? Would you say...

Every day

More than once a week

Once a week

At least once a month

Several times a year

Less often

Never

Don't know

25 (knowing) Which of these statements are closest to your own idea of God?

I don't believe in God

I don't know whether there is a God and I don't believe there is any way to find out

I don't believe in a personal God, but I do believe in a Higher Power of some kind

I find myself believing in God some of the time, but not at others

While I have doubts, I feel that I do believe in God

I know God really exists, and I

have no doubts about that

I don't know 
group reporting "never". We reduced the item concerning the idea of God (item 25) into four subgroups as well. The first three subgroups based on each of the first three possibilities of answers and the fourth subgroup based on a sum of the last three possibilities: first, one group of non-believers; second, a group of agnostics; third, (the biggest group) reporting belief in a higher power; and fourth, a group reporting belief in some kind of god.

\section{Results}

The initial retrieval of 1291 mothers was reduced by 378, either because of a research or address protection $(n=370)$, or caused by emigration or termination of pregnancy before the 10th week $(n=8)$. Research or address protection can be obtained easily in Denmark due to the Danish Act on Processing of Personal Data. Of the 913 mothers included, 517 responded, preterm mothers accounting for $26 \%$ and full term mothers accounting for $74 \%$. See the dropout flow chart (see Fig. 1).

In relation to differences between respondents and non-respondents, no statistically significant difference was found related to marital/cohabitant status or mode of birth, defined by caesarean birth versus vaginal birth $(p=0.88)$ or neonatal outcome $(p=0.12)$. Also there was no statistically significant difference related to time of birth (full term $=58 \%$ vs. preterm $=53 \%$ ) (See Table 2). Eighty-two percent of the respondents were members of the Danish national Church compared to $72 \%$ of the non-respondents with a statistical significant difference between respondents and non-respondents $(p<0.001)$.

\section{Respondents}

A total of 517 participants with a mean age of 29.6 years returned a completed questionnaire. We did not find statistically significant differences between full-term FT and PT mothers in relation to age, educational level or way of living. Eighty-nine percent reported living with a partner. Fifty-seven percent had completed a bachelor's or master's degree, whereas $9 \%$ reported having no vocational education at all. However, we did find differences in the mode of birth and the experience of perinatal or post partum death, since the prevalence of caesarean births and loss of a child are higher among PT mothers. Overall, $28 \%$ had a caesarean section, and $7 \%$ experienced the loss of the child with statistically significant differences between the two groups (see Table 3).

More than half ( $56 \%$ ) of the mothers reported being a religious person (in the Danish version the wording is more similar to "a believing person"), and $33 \%$ reported some kind of belief in God, when asked what their own idea of God was. Belief in some kind of higher power was reported by $37 \%$. Praying outside religious services once a month or more was reported by $21 \%$ and $39 \%$ reported prayer as rarely as less often than once a year. There were no statistical significant differences between FT and PT mothers in the three items concerning beliefs.

\section{Prayer and meditation}

Of the 517 respondents, 334 (65\%) confirmed having prayed or meditated, with a difference between FT and PT mothers $(p=0.05)$ which vanished when controlling for perinatal or post partum loss and mode of birth $(p=0.4)$. RR of prayer/meditation related to perinatal or post partum loss alone was 1.25 (data not shown). Of the mothers, 166 denied having prayed or meditated and 17 did not answer the question. The mothers practiced prayer rather than meditation (286 versus 89 mothers, $p<0,001)$ See Tables 4 and 5 .

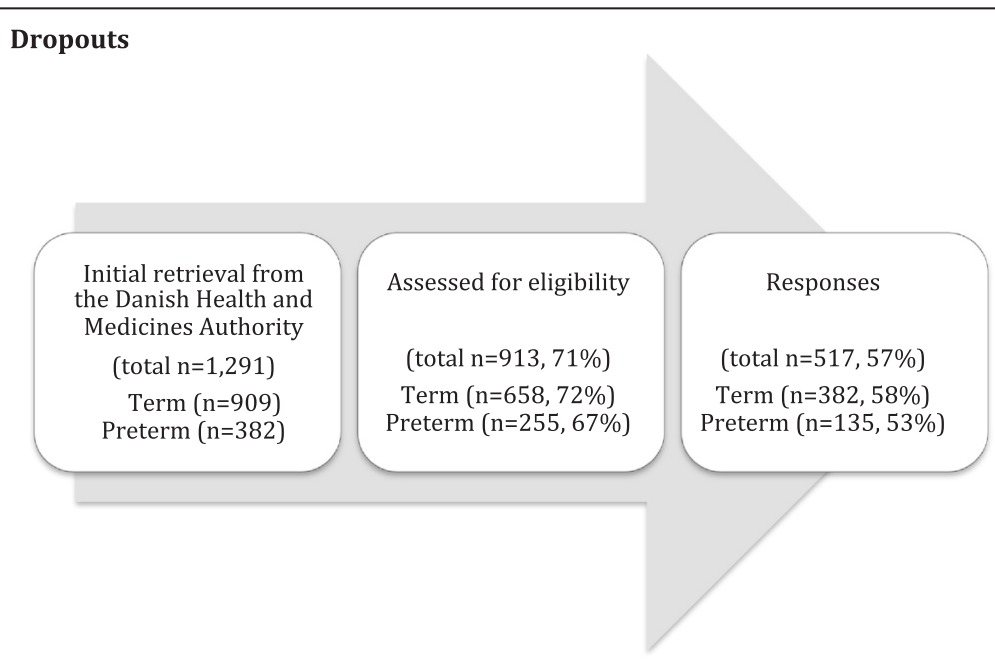

Fig. 1 Dropouts 
Table 2 Characteristics of respondents versus non-respondents, numbers (column percentages) of Danish first-time mothers invited to a cross-sectional survey on existential meaning-making in 2011

\begin{tabular}{llll}
\hline & $\begin{array}{l}\text { Non-respondents } \\
\text { Respondents } n(\%)\end{array}$ & $\begin{array}{l}\text { Respondents } \\
n(\%)\end{array}$ & $P$ \\
\hline Term mothers & $396(43)$ & $517(57)$ & \\
Preterm mothers & $276(70)$ & $382(74)$ & 0.16 \\
Age, years mean & $120(30)$ & $135(26)$ & \\
Married/civil partnership & $396(27.9)$ & $517(29.6)$ & $<0,001$ \\
Not married, cohabiting & $174(44)$ & $217(42)$ & 0.52 \\
$\begin{array}{l}\text { Membership of the Danish } \\
\text { national church: Yes }\end{array}$ & $214(54)$ & $294(56)$ & \\
$\begin{array}{l}\text { No } \\
\text { Caesarean birth }\end{array}$ & $113(28)$ & & \\
$\begin{array}{l}\text { Vaginal birth } \\
\text { Mothers not experiencing }\end{array}$ & $119(30)$ & $423(82)$ & $<0.001$ \\
$\begin{array}{l}\text { perinatal or post } \\
\text { partum loss }\end{array}$ & $277(70)$ & $372(70)$ & \\
$\begin{array}{l}\text { Mothers experiencing } \\
\text { perinatal or post } \\
\text { partum loss }\end{array}$ & $38(10)$ & $482(93)$ & 0.12 \\
\hline
\end{tabular}

${ }^{a}$ Widows and divorced mothers not included $(n=14)$

When dichotomizing the options of prayer or meditation, we found no statistically significant differences between FT mothers and PT mothers in their choices of prayer $(p=0.86)$ or meditation $(p=0.30)$ (data not shown). Respondents could choose several of the different forms of prayer or meditation. 11 did not choose any of the options, even though they had said that they prayed or meditated in the introductory question. Among the different forms of prayer, most mothers responded to the option of "prayer as an inner dialogue addressed to God" (46\%), followed by "prayer as an inner dialogue addressed to something greater than myself" (40\%). In relation to meditation, most mothers responded to the option "meditation as a means to maintaining or achieving good mental health" (19\%). We conducted sub-analyses by investigating every possibility of praying or meditation, and found no statistically significant differences in responses from FT and PT mothers in any the items. See Fig. 2.

\section{Discussion}

In the discussion, we address firstly the number of mothers responding affirmatively to prayer/meditation. Secondly, we address the differences when separating prayer and meditation in their answers, and thirdly, the lack of differences between FT and PT mothers.

In this cross-sectional survey among first time mothers in a secular society, we found that $65 \%$ of the
Table 3 Characteristics of full-term mothers versus preterm mothers, numbers and column percentages

$$
\begin{array}{llll}
\text { All N (\%) } & \text { FT mothers } & \text { PT mothers } & P \\
(n=517) & N(\%)(n=382) & N(\%)(n=135)
\end{array}
$$

Socioeconomic factors

$\begin{array}{lllll}\text { Age, years mean } & 29.6 & 29.5 & 29.9 & 0.44\end{array}$

Living with $461(89) \quad 341(89)$

$120(88)$

0.72

a partner

Bachelor level

$157(32) \quad 113(31)$

44 (35)

0.88

No vocational

47 (9) $\quad 36(10)$

11 (9)

education Short

167 (34) $125(34)$

$42(33)$

Bachelor level

$157(32) \quad 113(31)$

44 (35)

Master level

$122(25) \quad 92(25)$

$30(23)$

Obstetric factors

Caesarean section

$145(28) \quad 80(21)$

$65(48)$

$<0.001$

Having experienced 35 (7) 1(0.3)

perinatal or post

$34(25)$

partum loss

Spiritual basic factors

Religious person

$287(56) \quad 212(56)$

$75(56)$

0.86

Prayer to God

$105(21) \quad 79(22)$

$26(20)$

0.7

outside service, at

least once a month

Prayer to God

$195(39) \quad 140(38)$

$55(42)$

0.7

outside service,

approx. once a year

Idea of God,

181 (37) 137 (38)

44 (34)

0.43

believing in

higher power

Idea of God,

believing in God

$162(33) \quad 114(31)$

$48(38)$

0.43

mothers responded affirmatively when asked if they had prayed or meditated. This is higher than the 2008 EVS, where $48 \%$ women (pregnancy status unknown) responded affirmatively to the same question [35]. It is also higher than the survey among patients and relatives at Rigshospitalet, where $62 \%$ participants responded affirmatively to the question [34]. In relation to the analyses of data from the EVS, it is suggested that having a child may be one of those life events that intensify religiosity [20]. This is found in a US longitudinal study focusing on lifelong religious development as well [51]. Andersen and colleagues find the doing-dimension to be

Table 4 Core question: Do you take some moments of prayer, meditation or contemplation or something like that? Relative risk proportion (RR) of PT mothers 96 (71\%) versus FT mothers 238 (62\%)

\begin{tabular}{llll}
\hline Item $28(95 \% \mathrm{Cl})$ & $\mathrm{RR}$ & ${\text { Adjusted } \mathrm{RR}^{\mathrm{a}}}$ & Adjusted RR \\
\hline Prayer and/or & $1.14(0.99-1.30)$ & $1.08(0.92-1.26)$ & $1.06(0.91-1.25)$
\end{tabular}
meditation

${ }^{a}$ Adjusted for perinatal or post partum loss

${ }^{\mathrm{b}}$ Adjusted for perinatal or post partum loss and mode of birth 
Table 5 Prayer or meditation among first time mothers in Denmark, confirming to have prayed and/or meditated

\begin{tabular}{llll}
\hline Prayer & Meditation & & \\
\hline & No & Yes & Total \\
No & 11 & 37 & 48 \\
Yes & 234 & 52 & 286 \\
Total & 245 & 89 & 334 \\
\hline
\end{tabular}

stable (measured by church attendance), whereas the dimension of "knowing", for example the conviction that the church is where their spiritual needs are best met, is affected by significant life events [20]. The first time mothers in this survey are not hospitalized, but seem to be engaged in existential meaning-making in a very concrete way. Prayer and meditation are concrete "doing" practices related to a transcendent dimension. The consent to such practices by the majority of the respondents challenges our understanding of these practices being mainly present in relation to traumatic life events such as sickness or death, including traumatic birth.

The respondents in this survey are mothers, not fathers, and perhaps mothers are more attuned to prayer and meditation? In 2012, the sociologists Trzebiatowska and Bruce proposed childbirth as one of the possible reasons for women being more religious than men [52]. One aspect is the focus on birth in most religions, which naturally brings women more in contact with religious reflections and rituals, e.g. christenings. Another aspect highlighted by Trzebiatowska and Bruce is the focus on the biological body in relation to pregnancy and childbirth, a focus seen in several religious settings, e.g. in relation to the regulation of food or sexuality. It is a focus likewise discernible in more spiritually oriented environments, as for example yoga or healing, where health-related benefits seem to be an important motivational factor for participating [52, 53]. This last aspect of the focus on the biological body fits the data in this survey, where the main motivational cause of meditation among respondents was the urge to achieve good mental health (19\% reported this). In this perspective, meditation can be seen as a lifestyle activity in line with healthy food and a fit body in order to stay balanced and energetic. Perhaps Danish mothers pray or meditate due to the ostensibly natural connection between birth and religious rituals, but it seems that more women consent to prayer or meditation than actually participate in religious rituals. This points to an intrinsic and individualistic religious and spiritual orientation - prayer or meditation are not connected to a special community, but can also be practiced alone when pregnant or as a way of coping or caring when giving birth or in the postnatal period [54]. An individualistic approach was also found in a Dutch nationwide survey comparing different kinds of praying. Banziger et al. argue likewise that their finding of a high affirmative response to what they describe as "meditative and impulsive prayer", is characteristic in secularized society, because of the individualized and non-institutionalized forms of religiosity and spirituality [55].

When separating prayer and meditation, this individualism in a prayer- or meditation practice persists. The initial hypothesis of more mothers responding affirmatively to meditation than prayer, due for example to the focus on spiritually oriented practices in antenatal classes, was not supported. The majority of mothers reported having prayed (286 versus 89 ), and among them, most endorsed the statement of having addressed their prayer to a personal God. However, in the background question on prayer to God outside religious services,

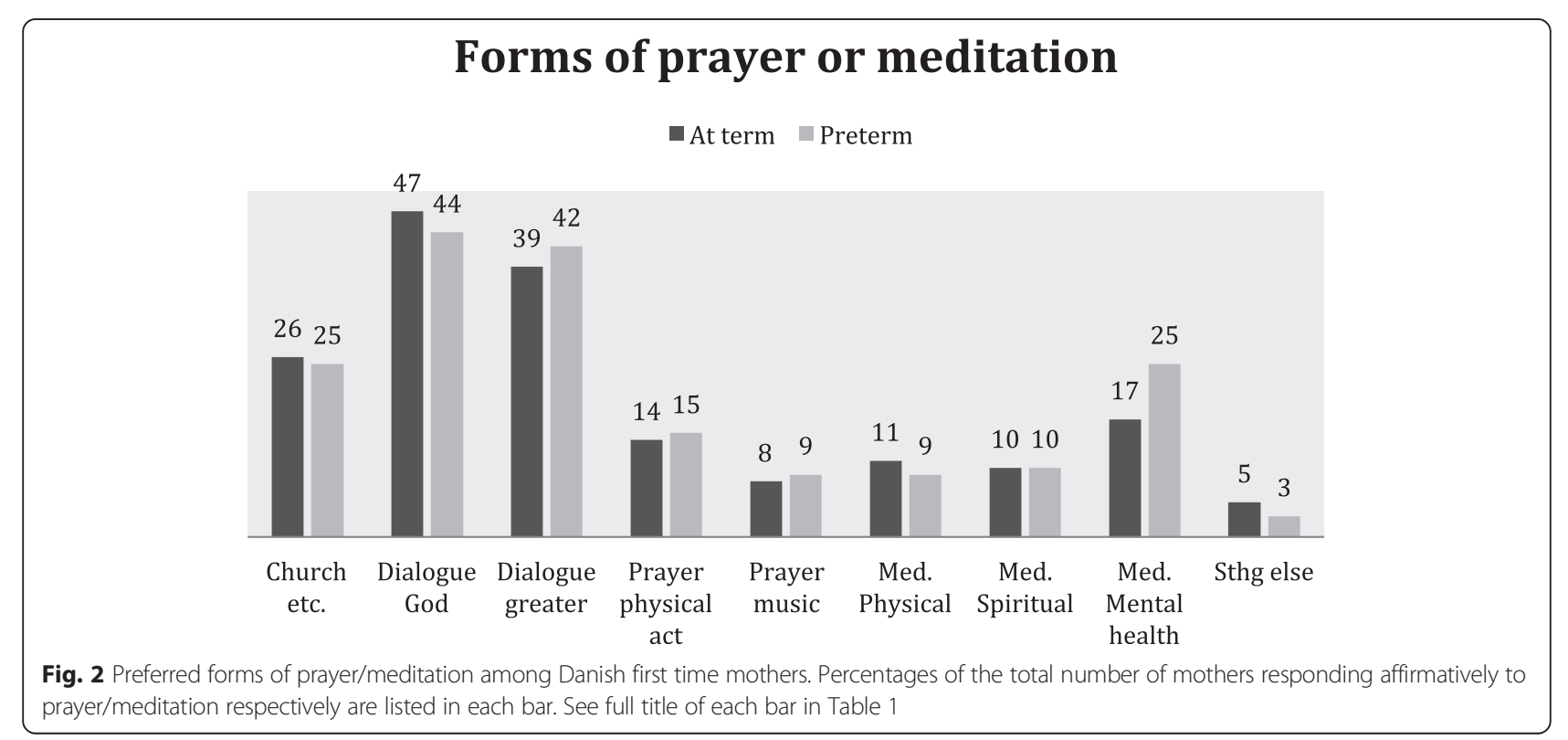


only $21 \%$ agreed, which supports the notion that questions loaded with a conventional understanding of religiosity as church attendance lead to more reluctant responses.

Andersen and Lüchau highlight the apparent paradox that religion has become more important to Danes, but individualized as well, when looking at religious data from the European Values Study. It seems that many contemporary Danes combine seeking answers in religion with doing this in their own individual way: there is a growing confidence in the church providing relevant answers to existential questions, but a receding belief in the church as a special authority [56]. In line with this, Danish researchers suggest Danes have trouble finding comfort in traditional religious beliefs, as Rosen found in a qualitative study in 2008 among Danes in the Copenhagen area: "I'm a believer - but I'll be damned if I'm religious" (Rosen 2009:161). When asked about their idea of God (the knowing dimension), more mothers in this survey reported belief in a higher power (37\%) than belief in some kind of God (33\%). "A higher power" is seen as a spiritual dimension of existential meaningmaking. This points to some inconsistency according to "the matrix" structure of the questionnaire, since most mothers at the same time affirmed some practice of prayer (the doing dimension), which is interpreted as a religious way of existential meaning-making. When most mothers report praying, this finding clashes to some extent with the expected widespread move from religious to more spiritual practices, including from prayer to meditation, predicted, for example, by two sociologists claiming a "spiritual revolution" on behalf of belief in a personal God [57]. After all, our findings fit in with other recent Danish data suggesting that Danes have not entirely left religious beliefs and practices in favor of practices of a more spiritual nature, of which meditation is an example [58].

One reason for the preference for praying rather than meditating among these new mothers may be that people in life transitions are emotionally dependent on strong relations. On the basis of neuroscientific research, Danish researchers argue, that improvised prayer is comparable to normal interpersonal interaction [59]. In prayer, the conceived relation to a God greater and beyond oneself may be a higher good than that gained in secular meditation practices, often characterized by contemplation within oneself [60]. For the new mother, the relation to her child has already had immense impact on her life, and perhaps, therefore, relating not only to a transcendent dimension (as in meditation), but also to a transcendent relation (as in praying to someone outside oneself) becomes important [61]?

So - at the same time as conventional religious beliefs are decreasing, women in this survey seem to practice praying as an inner dialogue with either a personal God or "something bigger than myself". There seems to be a combination of the highly individualistic way of making existential meaning of life combined with a widespread use of religious and spiritual practice deriving from a conventional religiously affiliated way of making meaning.

We looked into prayer and meditation practices among first time mothers of both preterm and full term children. Research suggests that traumatic childbirth, for example giving birth preterm, may actualize existential reflections, including religious practices, which ought to be addressed clinically [62]. Therefore, we expected to find a statistically significant difference in the use of prayer and meditation practices. We found a difference (not statistically significant though) between FT and PT mothers, however it vanished when controlling for perinatal or post partum loss and mode of birth. It seems that the loss of a child to a significant degree determined the finding related to prayer/meditation among PT mothers. When looking into specific ways of practicing prayer and meditation, we did not find any differences between FT and PT mothers either. The lack of difference contrasts with other findings from studies comparing experiences from FT and PT parents, showing PT parenthood to be traumatizing also in a long-term perspective [63-65]. Some studies find no differences when comparing FT and PT mothers, for example in relation to hopelessness, where ways of coping after having given birth have been compared in a Polish study [66].

In relation to prayer/meditation, the impact of childbirth and becoming a mother seem to affect the mothers in this study to equal extents. Although we did not find any statistically significant differences between FT and PT mothers in the study, it is obviously still possible that they differ in underlying motivations. Prayer and meditation practices may be motivated by a variety of feelings and experiences. Feelings of grief, loss and betrayal are described among mothers of preterm born children [67, 68], and may motivate prayer and meditation practices, as well as the described feelings of gratitude and joy when becoming a mother $[12,14]$.

\section{Limitations}

Of the 1291 mothers, only $71 \%$ could be contacted, mainly due to address and research protection. The final respondent rate of $57 \%$ may seem low, but is not unusual. The 2009 Views and Values Survey from the Danish Twin Registry had a respondent rate of $55 \%$, even though twins are usually willing participants [69]. We sought to resist selection bias through the drop-out analysis, thereby making the differences between respondents and non-respondents transparent [48]. It is seen that more respondents than non-respondents are members of the Danish National Church. Researchers propose Danes to 
be 'individualized' Christians where public religiosity and shared beliefs have diminished [70, 71]. This is reflected for example in churchgoing. Generally $78.4 \%$ of the population are members of the national church (2014), but only $10 \%$ attends church regularly (once a month ore more) [70, 72]. In our sample $6.6 \%$ report going to church regularly, which is even less than the average, and interpreted as an expression of membership of the church being more 'cultural' motivated than motivated by a public and shared religiosity $[70,73]$.

The apparently high proportion of respondents replying affirmatively to prayer and meditation, and the lack of differences between preterm and full term mothers, may be due to the time frame, since the mothers in this study gave birth 6-18 months prior to the survey. Answers might have differed if mothers had been asked earlier in the post partum period, assumedly increasing the difference between FT and PT mothers. The use of prayer and/or meditation has been investigated earlier in Denmark among other groups of people, but not the distinction between different kinds of religious activities, which renders a comparison of the data impossible. Due to the cross-sectional design, changes over time in answers cannot be compared either [74]. We still lack knowledge of the frequency of religious or spiritual practices among new mothers, of their motivation to practice prayer/meditation, and of the content or significance of prayer/meditation in relation to making meaning of having become a mother.

\section{Conclusions}

Firstly, we found that $65 \%$ of Danish first time mothers reported having had moments of prayer or meditation 6-18 months post partum. Secondly, when separating prayer and meditation in the core question, we found that mothers practiced prayer more than meditation. Amongst the five prayer options, most of the practicing mothers chose the option, "prayer as an inner dialogue addressed to God" (46 \%). Amongst the three meditation options, most mothers chose the option, "meditation as a means to maintaining or achieving good mental health" (19\%). Thirdly, we found no differences in the frequency of prayer or meditation between full term and preterm mothers when controlling for perinatal or post partum loss or mode of birth.

It seems that specific practices of existential meaningmaking, namely prayer and/or meditation, are indeed found among Danish first time mothers, and yet we know only little about the character or importance of these practices. To do so, qualitative research is needed to supplement this explorative overview. Also more research is needed to include attitudes and the nature of existential meaning-making among new fathers.

\section{Endnotes}

${ }^{1}$ In the preparation of this article, data from The Danish Views and Values Survey 2008 is used. Originally professor Peter Gundelach, Institute of Sociology, University of Copenhagen, conducted the survey. The data material was available through 'Danish Data Archive' (number DDA-21432). Prinds et al. are responsible for the analyses and interpretation of data in this paper.

\section{Competing interests}

The authors declare that they have no competing interests.

\section{Authors' contributions}

$\mathrm{CP}$ and $\mathrm{NCH}$ conceived the study and developed the questionnaire. CP, AS and $\mathrm{DH}$ planned the analyses, AS and CP prepared the data set for analyses and $\mathrm{CP}, \mathrm{DH}$ and $\mathrm{AS}$ conducted the analyses. $\mathrm{CP}, \mathrm{NCH}, \mathrm{OM}$ and $\mathrm{DH}$ interpreted the analyses. CP drafted the manuscript, and all authors critically revised the manuscript. All authors read and approved the final manuscript.

\section{Acknowledgements}

The first author thanks psychologist Peter la Cour, PhD, for interpretational support and expertise when developing the questionnaire from Professor Kenneth I. Pargament and Professor Annette Mahoney at Bowling Green State University, Ohio.

\section{Author details}

${ }^{1}$ Department of Clinical Institute, University of Southern Denmark, J.B. Winsløws Vej 19, DK-5000 Odense, C, Denmark. ${ }^{2}$ University College South Denmark, Degnevej 16, 6705 Esbjerg $\varnothing$, Denmark. ${ }^{3}$ Institute of Public Health, University of Southern Denmark, J.B. Winsløws Vej 9, DK-5000 Odense C, Denmark. ${ }^{4}$ Department of Gynaecology and Obstetrics, Odense University Hospital, Sdr. Boulevard 29, DK-5000 Odense C, Denmark.

Received: 30 October 2015 Accepted: 8 January 2016

Published online: 19 January 2016

\section{References}

1. Edwards A, Pang N, Shiu V, Chan C. Review. The understanding of spirituality and the potential role of spiritual care in end-of-life and palliative care: a meta-study of qualitative research. Palliat Med. 2010;24(8):753-70.

2. Koenig HG, King DE, Carson VB. Handbook of religion and health. Second edition ed. New York: Oxford University Press; 2012.

3. Williams A. Perspectives on spirituality at the end of life: a meta-summary. Palliat Support Care. 2006:4(4):407-17.

4. Hermann CP. The degree to which spiritual needs of patients near the end of life are met. Oncol Nurs Forum. 2007:34(1):70-8.

5. Sundhedsstyrelsen. Anbefalinger for den palliative indsats (the National service framework on palliative care). Sundhedsstyrelsen: København; 2011.

6. Sundhedsstyrelsen. Anbefalinger for svangreomsorgen (The National Service Framework on Maternity Services). In: Forebyggelse Cf, editor. Second edition ed. Copenhagen: Komiteen for sundhedsoplysning; 2013

7. Budin WC. Commentary. Birth and death: opportunities for self-transcendence. J Perinat Educ. 2001;10(2):38-42.

8. Kaufman SR, Morgan LM. The anthropology of the beginnings and ends of life. Annu Rev Anthropol. 2005:34:317-41.

9. The SD, Constellation M. A unified view of parent-infant psychotherapy. London: Karnac Books; 1995.

10. Raphael-Leff J. Psychological Processes of Childbearing. London: Chapman \& Hall; 1991

11. Gennep VA. The rites of passage. Chicago: University of Chicago Press; 1966

12. Crowther S, Smythe E, Spence D. The joy at birth: an interpretive hermeneutic literature review. Midwifery. 2014;30(4):e157-65.

13. Dahlen $H G$, Barclay LM, Homer CS. Processing the first birth: journeying into motherland. J Clin Nurs. 2010;19(13/14):1977-85.

14. Kitzinger S. Rediscovering birth. London: Pinter \& Martin Ltd; 2011.

15. Klassen PE. Blessed events: religion and home birth in America. Princeton: University Press; 2001.

16. Gaskin IM. Spiritual midwifery. Summertown, Tennessee: Book Publishing Company; 2002 
17. Zuckerman P. Society without God: what the least religious nations can tell us about contentment. New York: NYU Press; 2008.

18. Pedersen H. Religiosity and coping in a secular society: Prevalence, characteristics, and associations to quality-of-life among Danes facing life-threatening lung disease and other stressful life events [PhD]. Denmark: Århus University; 2013

19. Ausker N. Tid til forandring? Forhandlinger af religiøs kontinuitet, forandring og forbrug hos kræftpatienter i Danmark [Doctoral Thesis]. Copenhagen: University of Copenhagen; 2012.

20. Andersen PB, Ausker NH, la Cour P. Går fanden i kloster, når han bliver gammel? religiøsitet i lyset af sociale og psykologiske forhold. (will the devil enter a monastry when he is old? religiousity in the light of social and psychological conditions.). In: Gundelach P, editor. Små og store forandringer. Danskernes værdier siden. København: Hans Reitzels Forlag; 1981. p. 97-114.

21. Holditch-Davis D, Bartlett TR, Blickman AL, Miles MS. Posttraumatic stress symptoms in mothers of premature infants. J Obstet Gynecol Neonatal Nurs. 2003;32(2):161-71.

22. Borghini A, Pierrehumbert B, Miljkovitch R, Muller-Nix C, Forcada-Guex $\mathrm{M}$, Ansermet F. Mother's attachment representations of their premature infant at 6 and 18 months after birth. Infant Mental Health J. 2006; 27(5):494-508.

23. WHO, Dimes Mo, PMNCH, Children St. Born Too soon: the global action report on preterm birth. Geneva: World Health Organization; 2012.

24. Elklit A, Hartvig T, Christiansen M. [Stress disorder in parents of premature neonates-secondary publication]. Ugeskrift for Læger (Danish Medical Journal). 2008;170(45):3643-5.

25. Haslund $\mathrm{H}$. En antropologisk analyse af forældreskab efter præmaturitet. (An anthroplogical analysis of parenthood after preterm birth) [PhD Thesis]. Aarhus: Aarhus University; 2013

26. Rigtrup D. Ritual og mening. En religionsfilosofisk og ritualteoretisk undersøgelse af ritualets betydning i krisesituationer med udgangspunkt i casestudier af nøddåb. [Ph.D. Thesis]. Denmark: University of Copenhagen; 2013

27. Koenig H. Religion and medicine I: historical background and reasons for separation. Int J Psychiatry Med. 2000;30(4):385-98.

28. Koenig H. Medicine and religion. N Engl J Med. 2000:343(18):1339-40. author reply 41-2.

29. Hall J. Birth and spirituality. In: Downe S, Davis-Floyd R, editors. Normal childbirth: evidence and debate. Churchill livingstone. 2008. p. 47-67.

30. la Cour P, Hvidt NC. Research on meaning-making and health in secular society: secular, spiritual and religious existential orientations. Soc Sci Med. 2010;71(7):1292-9.

31. Werner A, Uldbjerg N, Zachariae R, Wu CS, Nohr EA. Antenatal hypnosis training and childbirth experience: a randomized controlled trial. Birth. 2013;40(4):272-80

32. APA SLOW. antenatal traning programme including mindfulness. 2014

33. Yogacompany. Pregnancy yoga. 2014

34. Ausker N, la Cour P, Busch C, Nabe-Nielsen H, Pedersen LM. [Existential thoughts and religious life of Danish patients]. Ugeskrift for Læger (Danish Medical Journal). 2008;170(21):1828-33.

35. Datamateriale DDA-21432: Den danske værdiundersøgelse, 2008 [database on the Internet]. Dansk Data Arkiv 2009, 1. udgave (ved Birgitte Grønlund Jensen og Nanna Floor Clausen) 2009.

36. Hvidtjørn D, Petersen I, Hjelmborg J, Skytthe A, Christensen K, Hvidt NC. Familial resemblance in religiousness in a secular society: a twin study. Twin Res Hum Genet. 2013;16(02):544-53.

37. Callister LC. Making meaning: women's birth narratives. Am J Matern Child Nurs. 2004;33(4):508-18.

38. Institut SS. Tal og analyser - fødselsstatistikken 2012. (numbers and analyses medical birth statistics 2012) statens serum institut: statens serum institut. The division of health surveillance and research. 2012.

39. Edwards P, Roberts I, Clarke M, DiGuiseppi C, Pratap S, Wentz R, et al. Increasing response rates to postal questionnaires: systematic review. BMJ. 2002;324(7347):1183

40. Prinds C, Hvidtjorn D, Mogensen O, Skytthe A, Hvidt NC. Existential meaning among first-time full-term and preterm mothers: a questionnaire study. J Perinat Neonatal Nurs. 2014;28(4):271-9.

41. BEK nr 1149 af 30/09/2013 Bekendtgørelse om information og samtykke til deltagelse i sundhedsvidenskabelige forskningsprojekter samt om anmeldelse af og tilsyn med sundhedsvidenskabelige forskningsprojekter (Act regarding information and consent to research projects of Health
Sciences and in addtion reporting and surveillance of research projects of Health Sciences), (2013).

42. Fishman J. Social theory and ethnography: language and ethnicity in Eastern Europe. In: Sugar PE, editor. Ethnic diversity and conflict in Eastern Europe. Oxford: Clio Press; 1980. p. 347-71.

43. Gundelach P, Iversen H, Warburg M. I hjertet af Danmark - institutioner og mentaliteter. Hans Reitzels Forlag: Copenhagen; 2008.

44. Rasmussen CP. In good hands. Literature review and qualitative interviews focusing on the impact of existential and perhaps religious considerations among mothers of babies born prematurely. Denmark: University of Southern Denmark; 2008

45. Gundelach PE. Små og store forandringer. København: Hans Reitzel: Danskernes værdier siden; 1981.

46. Prinds C, Hvidt NC, Mogensen O, Buus N. Making existential meaning in transition to motherhood-a scoping review. Midwifery. 2014;30(6):733-41.

47. Nørregård-Nielsen $E_{1}$ Østergaard J. Test af spørgeskemaet. (testing the questionnaire). In: Hansen NM, Marckmann B, Nørregård-Nielsen E, editors. Spørgeskemaer i virkeligheden - målgrupper, design og svarkategorier. (Questionnaires in fact - audiences, design and response categories). 1. udgave, 3. oplagth ed. Samfundslitteratur: Copenhagen; 2012. p. 117-34.

48. Boynton PM, Greenhalgh T. Selecting, designing, and developing your questionnaire. BMJ. 2004;328(7451):1312-5.

49. Statacorp. Stata Statistical Software. College Station TX: StataCorp; 06/2013.

50. Schuman H, Presser S. Questions and answers in attitude surveys. New York: SAGE Publications Inc; 1996.

51. McCullough ME, Enders CK, Brion SL, Jain AR. The varieties of religious development in adulthood: a longitudinal investigation of religion and rational choice. J Personal \& Social Psychology July. 2005;89(1):78-89.

52. Trzebiatowska M, Bruce S. Why are Women more Religious than Men? Oxford: Oxford University Press; 2012.

53. Newham J. Complementary therapies in pregnancy: a means to reduce ill health and improve well-being? J Reprod and Infant Psychol. 2014;32(3):211-3.

54. Allport GW, Ross JM. Personal religious orientation and prejudice. J Pers Soc Psychol. 1967:5:432-43

55. Banziger S, Janssen J, Scheepers P. Praying in a secularized society: an empirical study of praying practices and varieties. Int J Psychol Relig. 2008; 18(3):256-65.

56. Andersen PB, Lüchau P. Individualisering og aftraditionalisering af danskernes religiøse værdier. Små og store forandringer- danskernes værdier siden. København: Hans Reitzels Forlag; 1981. p. 76-96.

57. Heelas $\mathrm{P}$, Woodhead $\mathrm{L}$. The spiritual revolution: Why religion is giving Way to sprituality. Religion and spirituality in the modern world. Oxford, UK: Blackwell Publishing; 2005.

58. Andersen PB, Gundelach P, Lüchau P. A spiritual revolution in Denmark? J Contemp Relig. 2013;28(3):385-400

59. Schjoedt U, Stødkilde-Jørgensen H, Geertz AW, Roepstorff A. Highly religious participants recruit areas of social cognition in personal prayer. Soc Cogn Affect Neurosci. 2009:4(2):199-207.

60. Wachholtz AB, Pargament Kl. Is spirituality a critical ingredient of meditation? comparing the effects of spiritual meditation, secular meditation, and relaxation on spiritual, psychological, cardiac, and pain outcomes. I Behav Med August. 2005;28(4):369-83.

61. Nielsen MV. Børnefamilier og kirke (families with young children and church). research project about church activities related to families with young children, focused on baby hymn singing as a recent example. Aarhus University: Department of Culture and Society - Study of Religion; 2014.

62. Davidson JERNF, Powers KMD, Hedayat KMMD, Tieszen MMDF, Kon AAMDF, Shepard EMDF, et al. Clinical practice guidelines for support of the family in the patient-centered intensive care unit: American College of critical care medicine task force 2004-2005. Critical Care Medicine February. 2007:35(2):605-22

63. Singer LT, Salvator A, Guo S, Collin M, Lilien L, Baley J. Maternal psychological distress and parenting stress after the birth of a very low-birth-weight infant. JAMA. 1999;281(9):799-805

64. Tooten A, Hoffenkamp HN, Hall RA, Braeken J, Vingerhoets AJ, van Bakel HJ. Parental perceptions and experiences after childbirth: a comparison between mothers and fathers of term and preterm infants. Birth. 2013:40(3):164-71.

65. Shaw RJ, Sweester CJ, St. John N, Lilo E, Corcoran JB, Jo B, et al. Prevention of postpartum traumatic stress in mothers with preterm infants: manual development and evaluation. Issues Ment Health Nurs. 2013;34(8):578-86. 
66. Marianczyk K, Libera A, Oleszczuk J. The feeling of hopelessness and ways of coping with stress in women after preterm delivery. Ginekol Pol. 2010;81(5):342-6.

67. Golish TD, Powell KA. 'Ambiguous loss': managing the dialectics of grief associated with premature birth. J Soc Pers Relat. 2003;20(3):309-34.

68. Lindberg B, Ohrling K. Experiences of having a prematurely born infant from the perspective of mothers in northern Sweden. Int J Circumpolar Health. 2008;67(5):461-71.

69. Hvidtjorn D, Petersen I, Hjelmborg J, Skytthe A, Christensen K, Hvidt NC. Familial resemblance in religiousness in a secular society: a twin study. Twin Res Hum Genet. 2013;16(2):544-53.

70. Andersen PB, Lüchau P. Individualisering og aftraditionalisering af danskernes religiøse værdier. (Indvidualization and loss of tradition of Danish religious values). In: Gundelach PR, editor. Små og store forandringer - Danskernes værdier siden 1981. København: Hans Reitzels Forlag; 2011. p. 76-96.

71. Viftrup DT. Personal Crisis, Religious Coping and Transformations. A Qualitative Study on Pentecostal Danes' Experiences of Religious Beliefs and Practises while facing a Crisis. [PhD]. Denmark: University of Southern Denmark; 2014

72. Kirkestatistik [database on the Internet]. Kirkeministeriet (Ministry of Ecclesiastical Affairs) 2015.

73. Rosen I. I'm a Believer - But I'll Be Damned if I'm Religious : Belief and Religion in the Greater Copenhagen Area: A Focus Group Study [PhD]. Centrum för teologi och religionsvetenskap, Lunds University. Sweden: Lunds University; 2009

74. Silva Dos Santos I. Cancer epidemiology: principles and methods. Lyon: International Agency for Research on Cancer: World Health Organization; 1999.

\section{Submit your next manuscript to BioMed Central and we will help you at every step:}

- We accept pre-submission inquiries

- Our selector tool helps you to find the most relevant journal

- We provide round the clock customer support

- Convenient online submission

- Thorough peer review

- Inclusion in PubMed and all major indexing services

- Maximum visibility for your research

Submit your manuscript at www.biomedcentral.com/submit 